\title{
Nexus Between Economic Growth and Inflation: Evidence from Bangladesh
}

\author{
Takrima Sayeda \\ Department of Tourism and Hospitality Management, University of Dhaka
}

\begin{abstract}
This paper analyzes the long run and short run relationship between economic growth and inflation in Bangladesh using annual data set during 1980 to 2016. The vector error correction model verified that there exists at least one co integrating relation among them. In the long run, the macroeconomic variables come back to the equilibrium through the error correction term of -0.4306 . But in the short run, the model could not show any such features.
\end{abstract}

Keywords: Inflation, Growth, Cointegration, Vector Error Correction Model (VECM)

JEL Classification: C22, E31, O11

DOI: $10.7176 / \mathrm{JESD} / 10-16-03$

Publication date: August $31^{\text {st }} 2019$

\section{Introduction}

Economic growth and inflation are the two important macroeconomic indicators that play an important role in any economy. However, the extent of their relation is always a matter of debate in economics literature. Whether inflation is essential for economic growth or detrimental evokes controversy both theoretically and empirically. Keynes (1936) stated that there is a short run relationship exist between output and change in price level, whereas, no long run relationship could be possible. Friedman (1992) asserted, "Inflation is always and everywhere a monetary phenomenon". The quantity theory of money states that there is a one to one relationship between money supply and inflation because of classical dichotomy. Mundell (1965) and Tobin (1965) argue that the inflation causes individual to substitute money into interest earning assets, which leads to higher capital accumulation and thereby, stimulating a positive economic growth. Conversely, Fischer and Modigliani (1978) indicate a negative and nonlinear relationship between inflation and economic growth. During 1970s, a handful amount of studies have been conducted to find out the effect of inflation on economic growth. Economies around that time were experiencing hyperinflation and massive unemployment. Research finding showed that persistent high inflation could have an adverse consequence on the real economic growth even in the long run (Barro, 1995). Thus, the controversy persists regarding the relationship between inflation and economic growth. Apart from the relation controversy, the causation between inflation and economic growth is another debatable standpoint.

Empirical findings are mainly divided into three sub groups. Some studies found a positive relationship between inflation and economic growth; some studies found that inflation has a negative and significant impact on economic growth. However, some studies found no meaningful relation between them.

Fischer (1993) first identified the possibility of a non-linear relationship between growth and inflation. He noted the existence of a positive relationship when the inflation rate is low and negative relationship when the inflation rate is high. Consecutively, Sarel (1996) tested for structural break in the relationship between growth and inflation. He found that inflation rate below 8 percent is slightly positive, though not significant, but inflation higher than 8 has got negative impact on growth, which is strong and statistically significant.

Mallik and Chowdhury (2001) found a longrun positive relationship between GDP growth rate and inflation for four Asian countries: Bangladesh, India, Pakistan and Sri Lanka. They argue moderate inflation is helpful for growth, but faster economic growth can be detrimental for inflation. Mubarik (2005) estimated a threshold level of inflation for Pakistan for the period of 1973 to 2000. His study reveals that if inflation exceeds 9 percent threshold level would adversely affect the economic growth. In line with Mubarik's finding, Munir and Mansur (2009) identified a nonlinear relationship between inflation and economic growth in Malaysia for the period of 1970-2005. They found a threshold level of inflation as 3.9 percent, above which economic growth act negatively and below which it promotes economic growth.

Umaru and Zubairu (2012) found a positive correlation between inflation and economic growth in Nigeria for the period of 1970-2010. They found a unidirectional causation running from GDP to inflation. Mahmoud (2015) shows a positive and significant relationship between inflation and economic growth in Mauritania for the period of 1990-2013.

Though the above studies reveal positive relationship between inflation and economic growth, existence of negative relationship is not rare. Barro (1995) endorses the negative relationship between inflation and economic growth by using a panel data for more than 100 countries. If country characteristics are kept constant, a 10 percentage point increase in inflation decrease the GDP growth rate per capita for 0.2-0.3 percentage points.

Malla (1997) conducted two separate empirical studies and have found distinct outcomes. He found a significant negative relationship between inflation and economic growth for OECD (Organization of Economic 
Cooperation and Development), whereas; found an insignificant relationship in case of Asian countries.

Bruno and Easterly (1998) find a negative relationship while using annual data of 26 countries during the period of 1961 and 1992. Faria and Carneiro (2001), by using a time series data in Brazil, found a negative relationship between inflation and economic growth in the short run but they found no long run relationship between them.

Ayyoub et al. (2011) found a negative and significant relationship in case of Pakistan for the period of 197273 to 2009-10. The study suggests that the existing inflation is harmful to the GDP growth of the economy after a certain threshold level.

For the five ASEAN countries (Indonesia, Malaysia, Philippines, Thailand and Vietnam) Thanh (2015) found a statistically significant negative relationship between inflation and economic growth. He uses panel smooth transition regression (PSTR) model to estimate the threshold level inflation ins its impact on economic growth.

Paul, Kearney and Chowdhury (1997) conducted a study on 70 countries for the period of 1960-1989. They could not find any uniform result, rather found no causality between inflation and economic growth in $40 \%$ of the countries; one third countries have unidirectional causality and one fifth of the countries showed bidirectional causality.

The empirical findings are mixed regarding the relationship between inflation and economic growth both in developing countries and developed countries. . However, the empirical work on inflation growth nexus is very scanty in case of Bangladesh. Therefore, this paper attempts to reexamine the relationship between inflation and economic growth in the context of Bangladesh.

Ahmed and Mortaza (2005) empirically observed the relationship between inflation and economic growth by taking the annual data for the period of 1980 to 2005 . They found a significant negative relationship. They have found a threshold level of inflation $(6 \%)$ and apprehend that inflation above the threshold level would have adverse affect on economic growth in Bangladesh. They use Engle-Granger cointegration procedure to establish the long run relationship. Rahman (2014) also found a negative relationship between inflation and growth in Bangladesh by taking the data of 1976 to 2011. Along with inflation, Rahman (2014) added trade openness. The study uses the Vector Auto-regression (VAR) methodology to investigate the linkage. Majumder (2016) uses Vector Error Correction Model (VECM) to investigate the relationship between inflation and economic growth in Bangladesh for the period of 1975 to 2013 . He found a statistically significant positive relationship between the rate of inflation and economic growth of GDP. Apart from inflation, money supply and remittances have been taken as independent variables.

\section{The Model Specification}

To examine the relationship between economic growth and inflation, we have incorporated five macroeconomic variables into the following econometric model. Therefore, our empirical analysis uses the following independent variables: rate of inflation, gross fixed capital formation, broad money or M2 and trade openness, while the dependent variable is the economic growth.

$$
y_{t}=\gamma_{0}+\gamma_{1} i n f_{t}+\gamma_{2} i n v_{t}+\gamma_{3} b r m_{t}+\gamma_{4} t r d_{t}+\varepsilon_{t} \ldots \ldots \ldots \ldots \ldots \ldots \ldots \text { (1) }
$$

Where $y$ is the growth rate of real GDP, inf is the growth rate of CPI, inv is the investment, gross capital formation as the percentage of GDP, brm is the broad money or M2 to GDP ratio, trd is trade openness ((Export+Import)/GDP) and $\varepsilon$ is the error term.

This study uses annual time series data for Bangladesh for the period of 1980 to 2016. The data are taken from World Bank and Knomea. This study is based on five macroeconomics variables. GDP growth is measured as annual percentage growth rate of GDP at US\$ with base year 2010. Inflation is measured annual percentage change in consumer price index. Investment is measured as fixed gross capital formation as percent of GDP. Broad money as the M2 to GDP ratio and trade openness is measured as the total trade (export+import) to GDP ratio. Choice of the variables is in line with the previous researches and availability of the data [Khan\& Senhadji (2010); Mubarik(2005); and Sergii(2009)].

\section{Descriptive Statistics}

Descriptive statistics of the sample data shows that the average value of the economic growth rate is $4.93 \%$, while the average rate of inflation is $7.38 \%$. Investment has average value of $21.75 \%$ and broad money has an average value of $36.18 \%$. In case of trade openness, it is $27.46 \%$.

Table 1: Descriptive Statistics

\begin{tabular}{|l|l|l|l|l|l|}
\hline Variables & $\mathrm{N}$ & Mean & SD & Min & Max \\
\hline GDP Growth rate & 36 & 4.93 & 1.47 & 0.82 & 7.23 \\
\hline Inflation & 36 & 7.38 & 3.19 & 2.01 & 15.40 \\
\hline Investment & 36 & 21.75 & 4.88 & 14.44 & 29.65 \\
\hline Broad Money & 36 & 36.18 & 16.93 & 14.06 & 66.87 \\
\hline Trade Openness & 36 & 27.45 & 10.05 & 15.57 & 47.15 \\
\hline
\end{tabular}




\subsection{Stationary of Data}

The stationarity of the series are checked by applying the Augmented Dickey-Fuller test, ADF (1981) and PhillipsPerron test, PP (1998). The summary of the both unit root tests of five variables are shown in the Table 2.

Table 2: Unit Root Test

\begin{tabular}{|l|l|l|l|l|l|l|l|l|}
\hline \multicolumn{2}{|l}{ Test for Non-stationarity of Variables (ADF) } & \multicolumn{2}{l|}{ Test for Non-stationarity of Variables (PP) } \\
\hline & Level & \multicolumn{2}{l|}{ First Difference } & \multicolumn{2}{l|}{ Level } & \multicolumn{2}{l|}{ First Difference } \\
\hline variables & No trend & with trend & No trend & with trend & No trend & with trend & No trend & with trend \\
\hline Y & -5.17 & -8.87 & -14.90 & -14.75 & -5.41 & -8.55 & -21.93 & -23.22 \\
\hline Inf & -3.40 & -3.32 & -7.10 & -7.31 & -3.36 & -3.32 & -8.10 & -10.11 \\
\hline Inv & -0.13 & -3.60 & -3.80 & -4.00 & -0.20 & -1.76 & -5.85 & -6.02 \\
\hline Brm & 0.66 & -1.92 & -4.59 & -4.60 & 0.58 & -1.80 & -4.53 & -4.50 \\
\hline Trd & -0.92 & -2.15 & -6.10 & -6.01 & -0.90 & -2.21 & -6.10 & -6.01 \\
\hline $1 \%$ sig & -3.63 & -4.23 & -3.63 & -4.24 & -3.63 & -4.23 & -3.63 & -4.24 \\
\hline $5 \%$ sig & -2.95 & -3.54 & -2.95 & -3.54 & -2.95 & -3.54 & -2.95 & -3.54 \\
\hline $10 \%$ sig & -2.61 & -3.20 & -2.61 & -3.20 & -2.61 & -3.20 & -2.61 & -3.20 \\
\hline
\end{tabular}

The tests of unit root show that GDP growth rate is stationary both in level and in first difference. The outcome is confirmed by both the ADF and PP test. But rest of the variables, like inflation, investment, broad money and trade openness are non stationary in the level form, but stationary or integrated to order one I (1), in the first difference. The outcome is consistent in both the ADF and PP test. Thus, all the variables are integrated of order one in their first differences. Therefore, they fulfill the pre condition to run the Johansen Cointegration (1990) test to check the long run relationship between the variables.

\subsection{Optimal Lag Length Selection}

After the unit root test, identify the maximum lag length of the model is necessary as Johansen Cointegration tests are sensitive to the lags used. The results are presented into table 3.

Table 3: Optimal Lag Length Selection

\begin{tabular}{|l|l|l|l|l|l|l|}
\hline lag & LogL & LR & FPE & AIC & SC & HQ \\
\hline 0 & -391.5452 & NA & 18840.21 & 24.03304 & 24.25978 & 24.10933 \\
1 & -255.6818 & $222.3219^{*}$ & $23.22215^{*}$ & $17.31405^{*}$ & $18.67451^{*}$ & $17.77180^{*}$ \\
2 & -242.0271 & 18.20624 & 51.65889 & 18.00165 & 20.49582 & 18.84086 \\
3 & -224.9624 & 17.5819 & 114.1749 & 18.48257 & 22.11046 & 19.70324 \\
4 & -196.2 & 20.91805 & 185.2883 & 18.25455 & 23.01616 & 19.85669 \\
\hline \hline
\end{tabular}

* indicates lag order selected by the criterion

LR: sequential modified LR test statistics (each at 5\% level)

FPE: Final prediction error

AIC: Akaike information criterion

SC: Schwarz information criterion

HQ: Hannan-Quinn information criterion

From table 3, we see the result of five lag selection criteria. Based on the minimum value of each criterion, the maximum number of lag should be taken is "one".

\subsection{Cointegration Test}

As our model pass through the necessary conditions of stationary at first difference, now we can apply the Johansen Cointegration test (1988) to enquire if there is any long run relationship among the five macroeconomic variables, especially any long run relationship between inflation and economic growth. The estimated results of the Johansen Cointegration are shown in table 4.

Table 4: Johansen Test for Cointegration

\begin{tabular}{|c|c|c|c|c|c|c|}
\hline Null Hypothesis & $\begin{array}{l}\text { Eigen } \\
\text { Value }\end{array}$ & $\begin{array}{l}\text { Trace } \\
\text { Statistics }\end{array}$ & $\begin{array}{l}\text { Critical } \\
\text { value at } 5 \% \\
(\mathrm{p} \text { value }\end{array}$ & $\begin{array}{l}\text { Max-Eigen } \\
\text { statistics }\end{array}$ & $\begin{array}{l}\text { Critical value } \\
\text { at } 5 \% \quad(p \\
\text { value**) }\end{array}$ & Conclusion \\
\hline None $(\mathrm{r}=0) *$ & 0.7074 & 74.6314 & $\begin{array}{l}69.8188 \\
(0.0196) \\
\end{array}$ & 43.0142 & $\begin{array}{l}33.8768 \\
(0.0031) \\
\end{array}$ & $\begin{array}{l}\text { One } \\
\text { cointegrating } \\
\text { equation }\end{array}$ \\
\hline At most $1(\mathrm{r}=1)$ & 0.3791 & 31.6172 & $\begin{array}{l}47.8561 \\
(0.6332)\end{array}$ & 16.68 & $\begin{array}{l}27.5843 \\
(0.6075)\end{array}$ & $\begin{array}{l}\text { no cointegrating } \\
\text { equation }\end{array}$ \\
\hline
\end{tabular}

$*$ indicates rejection of the hypothesis at 0.05 level

**Mackinnon-Haug_Michelis (1999) p values

Table 4 illustrates the existence of cointegration among the five variables and they are statistically significant. 
It confirms a long run relationship among GDP growth rate, inflation, investment, broad money and trade and they move together (Engle \& Granger, 1987). Both the Trace Test and Maximum Eigen Value Test indicates the one (1) cointegrating equation at the 0.05 levels. Thus the null hypotheses of no cointegration among the variables are rejected. These findings pass us through the application of the Vector Error Correction Model (1990) to identify the extent of long run relationship among the variables.

\subsection{Vector Error Correction Estimates}

Engle and Granger (1987) show that if the variables are co-integrated of same order, there exist a valid long run relationship, and then there exists a corresponding short run relationship. Therefore, error term can be treated as the "equilibrium error" in the following equation.

$$
u_{t}=y_{t}-\gamma_{0-} \gamma_{1} i n f_{t}-\gamma_{2} i n v_{t}-\gamma_{3} b r m_{t}-\gamma_{4} \operatorname{trd} t
$$

It is popularly known as the Granger's Representation theorem. The theorem states that if two variables are co-integrated, the relationship between the two can be expressed as error correction mechanism (ECM). As we have multivariate model, we use vector error correction mechanism (VECM) in the following equations:

$$
\begin{gathered}
\Delta y_{t}=\alpha_{10}+\sum_{i=1}^{m} \alpha_{11} \Delta y_{t-i}+\sum_{i=1}^{m} \alpha_{12} \Delta i n f_{t-i}+\sum_{i=1}^{m} \alpha_{13} \Delta i n v_{t-i}+\sum_{i=1}^{m} \alpha_{14} \Delta b r m_{t-i} \\
\quad+\sum_{i=1}^{m} \alpha_{15} \Delta t r d_{t-i}+\theta_{1} \hat{u}_{t-1}+\epsilon_{t} \ldots \ldots \ldots \text { (3) }
\end{gathered}
$$

The other four equations in the ECM model system are:

$$
\begin{aligned}
& \Delta i n f_{t}=\alpha_{20}+\sum_{i=1}^{m} \alpha_{21} \Delta y_{t-i}+\sum_{i=1}^{m} \alpha_{22} \Delta i n f_{t-i}+\sum_{i=1}^{m} \alpha_{23} \Delta i n v_{t-i}+\sum_{i=1}^{m} \alpha_{24} \Delta b r m_{t-i} \\
& +\sum_{i=1}^{m} \alpha_{25} \Delta t r d_{t-i}+\theta_{1} \hat{u}_{t-1}+\epsilon_{t} \ldots \ldots \text { (4) } \\
& \Delta i n v_{t}=\alpha_{30}+\sum_{i=1}^{m} \alpha_{31} \Delta y_{t-i}+\sum_{i=1}^{m} \alpha_{32} \Delta i n f_{t-i}+\sum_{i=1}^{m} \alpha_{33} \Delta i n v_{t-i}+\sum_{i=1}^{m} \alpha_{34} \Delta b r m_{t-i} \\
& +\sum_{i=1}^{m} \alpha_{35} \Delta t r d_{t-i}+\theta_{1} \hat{u}_{t-1}+\epsilon_{t} \ldots \ldots \ldots \ldots \ldots \\
& \Delta b r m_{t}=\alpha_{40}+\sum_{i=1}^{m} \alpha_{41} \Delta y_{t-i}+\sum_{i=1}^{m} \alpha_{42} \Delta i n f_{t-i}+\sum_{i=1}^{m} \alpha_{43} \Delta i n v_{t-i}+\sum_{i=1}^{m} \alpha_{44} \Delta b r m_{t-i} \\
& +\sum_{i=1}^{m} \alpha_{45} \Delta t r d_{t-i}+\theta_{1} \hat{u}_{t-1}+\epsilon_{t} \ldots \ldots \ldots \text { (6) } \\
& \Delta t r d_{t}=\alpha_{50}+\sum_{i=1}^{m} \alpha_{51} \Delta y_{t-i}+\sum_{i=1}^{m} \alpha_{52} \Delta i n f_{t-i}+\sum_{i=1}^{m} \alpha_{53} \Delta i n v_{t-i}+\sum_{i=1}^{m} \alpha_{54} \Delta b r m_{t-i} \\
& +\sum_{i=1}^{m} \alpha_{55} \Delta t r d_{t-i}+\theta_{1} \hat{u}_{t-1}+\epsilon_{t}
\end{aligned}
$$

where $\epsilon_{t}$ is the white noiseerror term and $\hat{u}_{t-1}$ is the lagged value of the error term in equation (2). Equation (2) states that $\Delta y$ depends on $\Delta i n f, \Delta i n v, \Delta b r m, \Delta t r d$ and also on the equilibrium error term. $\theta_{1}$ is known as the speed of adjustment indicating the weight of adjusted disequilibrium in the past. Since $\theta_{1}$ is expected to be negative, the term $\theta_{1} \hat{u}_{t-1}$ is negative, and therefore, $\Delta y_{t}$ will be negative to restore the equilibrium. Table 5 shows the vector error correction estimates.

Table 5: Vector Error Correction Estimates

\begin{tabular}{|l|l|l|l|l|l|}
\hline Error correction & $\mathrm{D}(\mathrm{Y})$ & $\mathrm{D}(\mathrm{INF})$ & $\mathrm{D}(\mathrm{INV})$ & $\mathrm{D}(\mathrm{BRM})$ & $\mathrm{D}(\mathrm{TRD})$ \\
\hline CointEq1 & $-0.4306^{*}$ & -0.8595 & -0.2239 & -0.1961 & -0.3780 \\
\hline SE & $(.1425)$ & $(0.3500)$ & $(0.0634)$ & $(0.2883)$ & $(0.4596)$ \\
\hline t-statistics & {$[-3.0215]$} & {$[-2.4552]$} & {$[-3.5301]$} & {$[-0.681]$} & {$[-0.822]$} \\
\hline
\end{tabular}

Standard errors are in ( ) and t-statistics are in [ ]. * Indicates significant at 0.05 level

The estimated coefficient of error correction term is significant at 5 percent significant level from inflation rate to GDP growth rate with appropriate negative sign. It indicates that in the long run if the series are out of equilibrium, GDP growth rate will adjust to reduce the equilibrium error. $43 \%$ (error correction term is 0.4306 ) of the deviation of the GDP growth rate from its long run equilibrium is corrected each year. When ECT is significant and has a negative sign, it indicates inflation has long run causality on GDP. It is shown in Appendix tableA1.

To check the short run causality, chi square value of Wald Statistics is used. Here the coefficient of inflation is c(3). If the coefficient of inflation c(3) influence the GDP growth rate, then we can assume that there is a short run causality running from inflation to GDP growth rate. The corresponding Chi-square probability is $65 \%$, which is more than $5 \%$. Therefore, we fail to reject the null hypothesis. It suggests that inflation can't instigate GDP growth rate in the short run. Table A2 in Appendix shows the least squares value. 


\subsection{Diagnostic test}

For diagnostics, Godfrey's LM test for serial correlation, Breusch-Pagan-Godfrey's heteroscedasticy test for heteroscedasticy and Jarque-Bera test for normality have been performed. The current model fulfills the required conditions, which are shown in Appendix table A3. So, we can claim that our model is efficient, as it is free from serial correlation; heteroscedasticity and the residuals are normally distributed.

Thus the robustness tests show that the estimated VECM model is statistically sound and fitted well.

\section{Concluding Remarks}

The present study investigates if there exist any long run or short run relationship between economic growth and inflation, in Bangladesh for the time period 1980 to 2016. In doing so, the present study uses the methodology of Johansen cointegration test and vector error correction mechanism, (VECM).

Augmented Dickey Fuller (ADF) test and Phillips Perron (PP) test have been carried out to check the stationarity. The test results indicate the existence of unit root at the levels but after first difference the variables become stationary.

Maximum lag length of one is confirmed by the LR, FPE, AIC, SC and HQ criterion. After that, Johansen cointegration test confirms one cointegrating equation by trace test and maximum eigenvalue test.

Consequently, the vector error correction mechanism confirms a significant long run association between economic growth and inflation. However, in case of short run, no such evidence is found.

\section{References}

Ahmed, S., \&Mortaza, G. (2005). Inflation and economic growth in Bangladesh: 1981-2005. Policy Analysis Unit (PAU) Working Paper 0604.

Ayyoub, M., Chaudhury, I.S., \&Farooq, F. (2011). Does inflation affect economic growth? The case of Pakistan. Pakistan Journal of Social Sciences (PJSS). 31(1): 51-64.

Barro, R.J. (1995). Inflation and economic growth. National Bureau of Economic Research (NBER) Working Paper 5326.

Bruno, M. \& Easterly, W. (1998). Inflation crises and long-run growth. Journal of Monetary Economics. 41(1): 3 26.

Dickey, D.A., \& Fuller, W. A. (1981). Likelihood ratio statistics for autoregressive time series with a unit root. Econometria, 49: 1057-1072.

Engle, R. F., \& Granger, C. W. J. (1987). Co-integration and error correction: representation, estimation and testing. Econometrica, 55: 1-87.

Faria, J. \&Carneiro, F. (2001). Does high inflation affect growth in the long and short run? Journal of Applied Economics. 4: 89-105.

Fischer, S. (1993). The role of macroeconomic factors in growth. . National Bureau of Economic Research (NBER) Working Paper 4565.

Fischer, S., \& Modigliani, F. (1978). Towards and the understanding of the real effects and costs of inflation. National Bureau of Economic Research (NBER) Working Paper No. 303.

Friedman, M. (1992). Money mischief: episodes in monetary history. New York:HarcountBracc Jovanovich.

Johansen, S. (1988). Statistical analysis of cointegration vectors. Journal of Economic Dynamics and Control, 12 : 231-254

Johansen, S., \&Juselius, K. (1990). Maximum likelihood estimation and inference on co-integration with the application to the demand for money. Oxford Bulletin of Economics and Statistics, 52: 169-210.

Keynes, JM. (1936). The general theory of employment, interest and money. London: Macmillan.

Khan, M., \& Senhadji, A. (2001). Threshold effects in the relationship between inflation and growth. IMF Staff Papers, 48(1): 1-21.

Mahmoud, L.O.M. (2015). Consumer price index and economic growth: a case study of Mauritania 1990-2013. Asian Journal of Empirical Research, 5(2): 16-23.

Majumder, S. (2016). Inflation and its impact on economic growth of Bangladesh. American Journal of Marketing Research, 2(1): 17-26.

Malik, G. \&Chowdhury, A. (2001). Inflation and economic growth: evidence from south Asian countries. Asian Pacific Development Journal, 8(1): 123-135.

Malla, S. (1997). Inflation and economic growth: evidence from a growth equation. Department of Economics, University of Hawa'I at Monoa.

Mubarik, Y. A. (2005). Inflation and growth: an estimate of the threshold level of inflation in Pakistan. State Bank of Pakistan Research Bulletin, 1(1): 35-44.

Mundell, R. (1963). Capital mobility and stabilization policy under fixed and flexible exchange rates. American Economic Review, 53: 112-119.

Munir, Q. \& Mansur, K. (2009). Nonlinearity between inflation rate and GDP growth in Malaysia. Economic 
Bulletin, 29(3): 1555-1569.

Paul, S., Kearney, C., \&Chowdhury, K. (1997) Inflation and economic growth: a multi-country empirical analysis. Applied Economics, 29(10): 1387-1401.

Phillips, P.C.B. \& Perron, P. (1998). Testing for a unit root in time series regression. Biometrika, 32: 301-318.

Rahman, Z. (2014). Inflation and economic growth in Bangladesh: an empirical analysis by using VAR model. Asian Journal of Empirical Research, 4(8): 404-420.

Sarel, M. (1996). Nonlinear effects of inflation on economic fgrowth. IMF Staff Papers, 43: 199-215.

Sergii, P. (2009). Inflation and economic growth: the non-linear relationship. Evidence from CIS Countries. MA Thesis in Economics, Kyiv School of Economics.

Thanh, S.D. (2015). Threshold effects of inflation on growth in the ASEAN-5 countries: a panel smooth transition regression approach. Journal of Economics, Finance and Administrative Science. 20: 41-48.

Tobin, J. (1965). Money and economic growth. Econometrica, 33: 671-684.

Umaru, A. \&Zubairu, A.A. (2012). Effects of inflation on the growth and development of the Nigerian economy: an empirical analysis. International Journal of Business and Social Sciences, 3(10): 183-191. 